\title{
PERSPECTIVES OF LITHOSPERMUM OFFICINALE L. CULTIVATION
}

\section{Andrushchenko Olena}

M.M. Gryshko National Botanical Garden of NAS of Ukraine, Kyiv, Ukraine

\section{ПЕРСПЕКТИВИ КУЛЬТИВУВАННЯ LITHOSPERMUM OFFICINALE L.}

\section{Андрущенко Олена}

Received 11.5. 2017

Revised 22. 5. 2017

Lithospermum officinale L. was used by people from ancient times as a magical, religious and medicinal plant. Lithospermum officinale is known for its useful properties as a medicinal and oilseed plant. Now it is of interest as a perspective source of fatty oils, medicinal raw materials, and biologically active compounds. Gromwell in the last century have met as usual in Europe, but researchers of modern flora refer to species that occur sometimes or are offered to regional security lists. In the case of industrial use, there is a need for the introduction of a gromwell into a culture. The features of Lithospermum officinale ontogeny during growing in the Forest-steppe zone of Ukraine are that in the first year of vegetation of plants there are all age states - from sprout to the generative age state, which ends with the formation of a small amount of viable seeds. After the cutting of the aboveground part, there was the formation of proleptic vegetative-generative shoots, on which buds, flowers, and several erems were formed. The formation of sylleptic shoots is characteristic of perennial plants in the second decade of March. When cultivating Lithospermum officinale in the studied conditions it is recommended a sowing before winter, or preliminary stratification of seeds. During spring sowing seedlings were obtained in the second half of May, and sown seeds before the winter - in early April. In laboratory conditions stratified Lithospermum officinale seeds sprouted on the $5^{\text {th }}$ day, germination was $72 \%$. Using of crops is possible in the second year of vegetation. Using of aboveground biomass in the budding phase is due to the high content of biologically active compounds. The content of sugars in the budding phase was 5.4-7.2\%, ascorbic acid - 236.3-373.9 mg\%, chlorophyll $a-1.39-1.49 \mathrm{mg} / \mathrm{g}$, chlorophyll $b-0.35-0.41 \mathrm{mg} / \mathrm{g}$ and carotenoids $-0.77-0.78 \mathrm{mg} / \mathrm{g}$. In culture conditions, the yield of biomass of the gromwell was $1.6 \mathrm{t} / \mathrm{ha}$, and the seeds $-287 \mathrm{~kg} / \mathrm{ha}$.

Keywords: Lithospermum officinale L.; ontogenesis; cultivation; gromwell stratification

\section{Вступ}

Рослини, що належать до роду Горобейник (Lithospermum L.) $з$ родини Boraginaceae Juss. з прадавніх часів використовуються людиною. Археологічні знахідки плодів свідчать про багатогранність його використання та присутність як елементу культури у населення різної географічної локалізації, що існувала у різні історичні епохи. Найбільш ранні артефакти пов'язані із культурою Кукутень-Трипілля, які датуються V-IV тисячоліттям до н. е. (Solcan et al., 2014). Плоди Lithospermum officinale L. виявлені у похованні раннього бронзового періоду в с. Шарбя

*Corresponding author: Olena Andrushchenko, M.M. Gryshko National Botanical Garden of NAS of Ukraine, Kyiv, Ukraine, $\bowtie$ novaflora@ukr.net 
у Польщі (Baczynska and Litynska-Zajac, 2005). У гробниці Янгхай (Китай, I тисячоліття до н. е.) знайдено бочки, краї яких оздоблені орнаментом із плодів Lithospermum officinale (Hong-En et al., 2007). На думку дослідників використання плодів горобейника виконувало певні соціальні функції і свідчило про багатство, силу та престиж у суспільстві. Імовірно воно мало також символічне значення, виступаючи елементом намиста або мозаїки (Solcan et al., 2014), та використовувалося як магічний компонент у лікувальних засобах (Baczynska and LitynskaZajac, 2005).

Lithospermum officinale відомий своїми корисними властивостями як лікарська та олійна рослина (1987). Для виробництва він являє інтерес як перспективне джерело жирної олії. Його насіння містить до 15 \% жирної олії, цінної для косметичної промисловості і фармакології, оскільки поліненасичені жирні кислоти становлять 66 \% від їх загальної кількості (Kuhnt, 2012). Наприкінці XIX ст. горобейник лікарський на території Євразії був поширений переважно в середній Європі (від південної Скандинавії і Англії до Іспанії, Італії, Греції) та Західній і Середній Азії (Шмальгаузен, 1897). За зведенням кінця XX століття - на території України вважався звичайним (Определитель..., 1987). Дослідники сучасної флори відносять Lithospermum officinale до видів, що трапляються зрідка (Винокуров, 2014; Коломийчук, 2016), та навіть пропонують до регіональних охоронних списків (Кузьмішина та ін., 2009).

У перспективі промислового використання виникає необхідність введення горобейника лікарського в культуру, оскільки ресурсні запаси, очевидно, не зможуть забезпечити виробничі потреби.

\section{Матеріали та методи}

Насінний матеріал Lithospermum officinale (горобейник лікарський) був одержаний з Ботанічного саду Латвійського університету. Досліджували насіння власної репродукції. Його схожість перевіряли лабораторним методом, пророщуючи в чашках Петрі на зволоженому папері у термостаті при температурі $25^{\circ} \mathrm{C}$; стратифікація - при $+5{ }^{\circ} \mathrm{C}$ упродовж п'яти тижнів. Підзимовий висів насіння здійснювали в останню декаду листопада, весняний - наприкінці березня. Дослідні ділянки знаходились на території Національного ботанічного саду (НБС) ім. М. М. Гришка НАН України (Правобережний Лісостеп). Грунти темносірі, опідзолені, слабо змиті. Досліджено рослини 1-го, 2-го та 3-го років вегетації впродовж 2014 - 2016 років. Експерименти проводили у трикратній повторності. Вибірка при визначенні метричних показників становила 20 рослин. Використовували візуальні спостереження для визначення фенологічних фаз розвитку рослин. Хімічні аналізи проводили в біохімічній лабораторії відділу культурної флори НБС ім. М.М. Гришка. Вміст фотосинтетичних пігментів (хлорофілів і каротиноїдів) визначали спектрофотометрично; абсолютно суху речовину шляхом висушування зразків при температурі $105^{\circ} \mathrm{C}$ до постійної маси; вміст аскорбінової кислоти - за Ярусовою (Крищенко, 1983); загальний цукор - за А.В. Петербургським (1963).

\section{Результати та їх обговорення}

Горобейник лікарський - багаторічна трав'яниста рослина висотою 60 - 80 см із прямостоячим розгалуженим стеблом. Листки чергові, прості, цілокраї, ланцетні. Стебло і листки опушені жорсткими короткими притиснутими волосками. Квітки двостатеві, правильні, зібрані в завійки; віночок 46 мм завдовжки, блідо-жовтий. Плід - ценобій, що складається із чотирьох еремів.

Для культивування рослин насамперед необхідно дослідити етапи іiї ровитку. Особливості онтогенезу Lithospermum officinale полягають у тому, що у перший рік вегетації у рослин спостерігаються всі вікові стани - від проростку до генеративного вікового стану, який завершується утворенням невеликої кількості життєздатного насіння. 
Поява сходів спостерігається на 19 - 30 добу після весняної сівби залежно від забезпеченості вологою. Вегетативна фаза триває 77 - 78 діб. Фаза цвітіння наступала вже на 10 добу після початку бутонізації. Генеративний пагін наростає поступово із утворенням нових цимоїдів, тому одночасно на рослині відбувається бутонізація, цвітіння і плодоношення. Важливе значення має час висіву насіння. За весняної сівби сходи вдавалося отримати у другій половині травня, а висіяне насіння під зиму сходить вже на початку квітня (рис. 1). Це не впливало на насіннєву продуктивність, але підвищувало польову схожість рослин на $15 \%$.

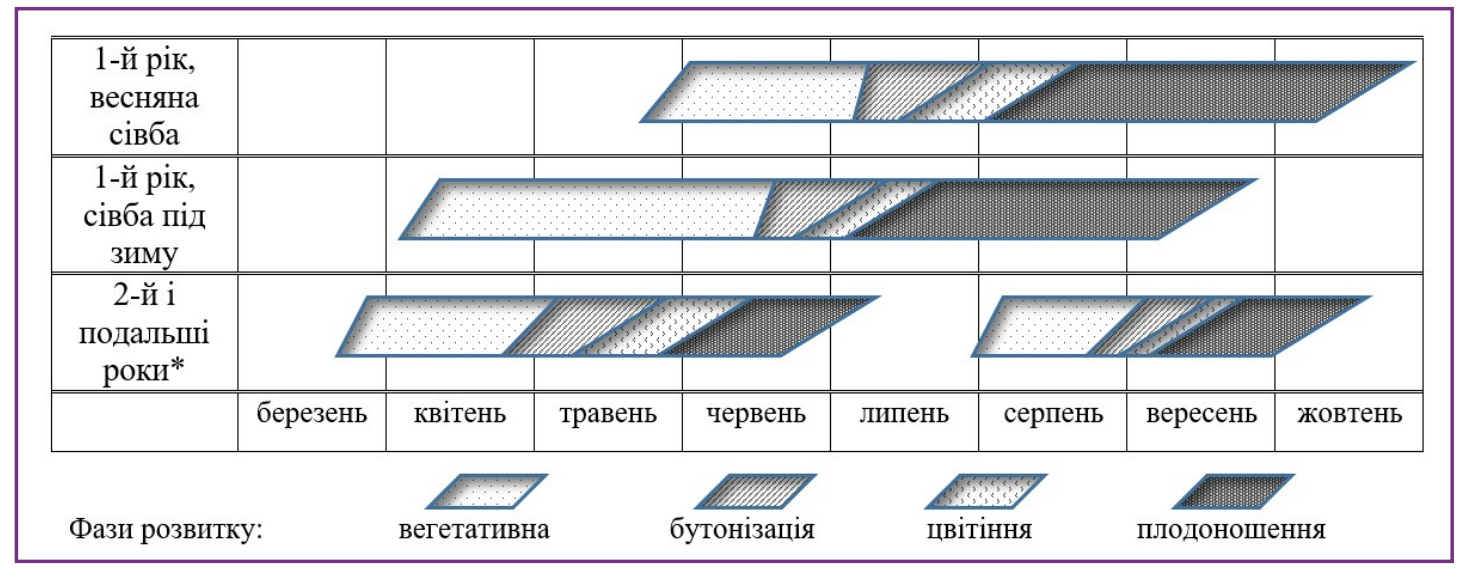

Рисунок 1 Феноспектри однорічних та багаторічних рослин Lithospermum officinale L. (2014 - 2016 рр.) Figure 1 Fenospectra of annual and perennials plants of Lithospermum officinale L. (2014-2016)

Суцвіття у рослин першого року життя слабо розвинуті і складаються з 2 - 3 рацемозних вісей, які несуть 4 - 10 цимоїдів. На місці кожної квітки формується в середньому 1 ерем.

Для рослин другого та наступних років життя характерне відростання силептичних пагонів у другій декаді березня. Генеративна фаза наступала через $42-44$ доби і завершувалася достиганням насіння у першій половині липня. У порівнянні із першим роком життя вегетативна фаза $\epsilon$ коротшою приблизно на 30 діб, а достигання насіння відбувалося на 2 місяці раніше. Після скошування надземної частини спостерігалося відростання пролептичних вегетативно-генеративних пагонів, на яких розпочиналися бутонізація, цвітіння і зав'язувалося кілька еремів. Слід відзначити, що на рослинах Lithospermum officinale, у яких після достигання насіння не були видалені силептичні пагони, розвиток пролептичних пагонів не відбувався. Ереми, що формуються у кількості від 1 до 4 у кожному цимоїді, після достигання залишаються триматися на плодоніжці до осені. Відсутність осипання насіння $\epsilon$ цінною господарською характеристикою.

Ереми горобейника лікарського мають міцну оболонку із гладенькою світло-сірою поверхнею, що робить їх за механічними та зовнішніми ознаками подібними до камінців. Насіння має фізіологічний спокій, тому проростання його тривале і неодночасне. Нами визначалася схожістьта енергія проростання в лабораторних умовах. Дані показники різнилися між собою залежно від способів передпосівної обробки. Енергія проростання насіння Lithospermum officinale слабо виражена, проростання насіння відбувалося протягом двох місяців. Найкраща схожість виявлена після стратифікації, яка становила 72 \% та у 1,5 рази перевищувала показник у контролі.

Біохімічні дослідження надземної частини рослин Lithospermum officinale виявили високий вміст сухої речовини, загального цукру та значну кількість аскорбінової кислоти. Біохімічний склад аналізували у двох фазах: бутонізації та плодоношення. Вміст сухої речовини 
більш ніж подвоювався на момент плодоношення з 21 до 48 \%. Кількість загального цукру у фазу бутонізації дещо вища і становить 5,4 - 7,2 \%, зменшуючись до 3,9 - 4,0 \%. Особлива відмінність між фазами виражалася у вмісті аскорбінової кислоти: 236,3 - 373,9 мг\% під час бутонізації та 12,9 - 10,0 мг\% під час плодоношення. Достатньо високий рівень кількості фотосинтетичних пігментів зафіксовано у фазу бутонізації: хлорофілу $a-1,39-1,49$, хлорофілу $b-0,35-0,41$ і каротиноїдів - 0,77 - 0,78 мг/г.

Досліджуючи продуктивний потенціал Lithospermum officinale в умовах польової культури з'ясували, що дворічні рослини, висіяні із шириною міжрядь 45 см, здатні утворити 1,6 т/га біомаси. Реальна урожайність насіння становила 287, тоді як потенційна - 509,6 кг/га.

\section{Висновки}

При культивуванні Lithospermum officinale в умовах Лісостепу України рекомендовано здійснювати посів під зиму, або попереднє стратифікування насіння. В лабораторних умовах стратифіковані ереми Lithospermum officinale проростали на 5-у добу, схожість становила 72 \%. Експлуатація посівів можлива на другий рік вегетації. Використання надземної біомаси у фазу бутонізації обумовлене підвищеним вмістом біологічно активних сполук. В умовах культури урожайність біомаси горобейника лікарського становила 1,6 т/га, а насіння - 287 кг/га.

\section{Література}

Baczynska, B., Litynska-Zajac, M. 2005. Application of Lithospermum officinale L. in early Bronze Age medicine. Vegetation History and Archaeobotany, vol. 14, no. 1, p.77-80.DOI:10.1007/s00334-004-0054-7

Hong-En, J., Xiao, L., Chang-Jiang, L., Yu-Fei, W., Cheng-Sen, L. 2007. Fruits of Lithospermum officinale L. (Boraginaceae) used as an early plant decoration (2500 years BP) in Xinjiang, China. Journal of Archaeological Sciense, vol. 34, no. 2, p. 167-170. https://doi.org/10.1016/j.jas.2006.04.003

Kuhnt, K. 2012. Searching for health beneficial n-3 and n-6 fatty acids in plant seeds. Eur. J. Lipid Sci. Technol, vol. 114, no. 2, p. 153-160. DOI: 10.1002/ejlt.201100008

Solcan, L., Danu, M., Irimia, I., Bodi, G. 2014. Use and possible significance of two species of Boraginaceae family in prehistory - a review of the Cucuteni culture finds. An. Stiint. Univ. Al. I. Cuza lasi, Sect. II a. Biol. veget., vol.60, no. 2, p.63-75. http://www.bio.uaic.ro/publicatii/anale_vegetala/issue/2014F2/072014F2.pdf

Винокуров, Д.С. 2014. Синтаксономія ксеротермної рослинності долини р. Інгул (Клас FestucoBrometea). Частина 2. Лучно-степова, чагарниково-степова, справжньостепова рослинність. Укр. бот. журн., т. 71, № 5, с. 537-548.

Коломійчук В. 2016. Ботанічна характеристика проектованого заказника «Преславська лука» (Запорізька обл.). Інтродукція та збереження рослинного різноманіття, вип. 1(34), с. 19-23.

Крищенко В.П. 1983. Методы оценки качества растительной продукции. М.: Колос. 192 с.

Кузьмішина, ІІІ. 2009. Охоронний статус рідкісних та зникаючих видів рослин Шацького національного природного парку. Науковий вісник Волинського начіонального університету імені Лесі Українки, № 2, с. 27-31.

Определитель высших растений Украины. 1987. Под ред. Прокудина Ю. Н. Киев: Наук. думка. 548 с.

Петербургский А.В. 1963. Практикум по агрономической химии. Л.: Изд-во сельскохозяйственной литературы. 591 с.

Шмальгаузен, И.Ф. 1897. Флора Средней и Южной России, Крыма и Северного Кавказа. Руководство для определения семянных и высших споровых растений, т. 2. Двудольные сростнолепестные и безлепестные, однодольные, голосемянные и высшие споровые. Киев, тип. Т-ва печ. дела и торг. И.Н. Кушнерев и Ко в Москве, Киевск. отд-ние. XVI+752 с. 